\title{
Kinetika Pengeringan Cabai dengan Perlakuan Blansing Suhu Rendah-Waktu Lama
}

\section{Drying Kinetics of Chili with Low Temperature Long Time Blanching Treatment}

\author{
Andi Muhammad Irfan ${ }^{1, *}$, Nunik Lestari ${ }^{2}$, Arimansyah $^{1}$, A. Ramli Rasyid ${ }^{1}$ \\ ${ }^{1}$ Program Studi Pendidikan Teknik Mesin, Fakultas Teknik, Universitas Negeri Makassar, Jl. Daeng Tata \\ Raya, Parangtambung, 90224 Makassar \\ ${ }^{2}$ Program Studi Pendidikan Teknologi Pertanian, Fakultas Teknik, Universitas Negeri Makassar, \\ Jl. Daeng Tata Raya, Parangtambung, 90224 Makassar
}

*Penulis korespondensi: Andi Muhammad Irfan, e-mail: andimuhammadirfan@unm.ac.id

Tanggal submisi: 18 September 2020; Tanggal penerimaan: 15 Februari 2021

\begin{abstract}
This study was aimed to determine the drying kinetics of chilies that have been pretreated with low temperature long time (LTLT) blanching. Drying chilies with LTLT blanching pretreatment at 60,70 , and $80{ }^{\circ} \mathrm{C}$ for 20 minutes was assigned as treatment in this research. Drying chillies with high temperature short time (HTST) blanching pretreatment, without blanching pretreatment in the dryer, and without blanching pretreatment in direct sunlight were also studied as the comparison. The results showed that chilies treated with blanching pretreatment, both LTLT and HTST, have a faster drying rate and achieve the target moisture content faster than chilies that were not blanched. The color of dried chilies that were dried in a dryer was also better than dried chilies that were dried in the sun. Of all the blanching treatments, chilies with LTLT blanching pretreatment at $80^{\circ} \mathrm{C}$ for 20 minutes had the fastest drying rate, a drying time of 34 hours, and the attractive dried chilli color. The evaluation results also showed that the Page model was the most suitable model to describe the drying characteristics of chilies with LTLT pretreatment blanching, with $R^{2}$ ranging from 0.9913-0.9935, $X^{2}$ ranging from 0.0005-0.0009, and RSME ranging from 0.0221-0.0293.
\end{abstract}

Keywords: Chili; blanching; color; drying; mathematical model

(C) The Authors. Publisher Universitas Pattimura. Open access under CC-BY-SA license.

\begin{abstract}
ABSTRAK
Penelitian ini bertujuan untuk mengetahui kinetika pengeringan cabai yang diberi perlakuan awal low temperature long time (LTLT) blanching atau blansing pada suhu rendah dalam waktu yang relatif lama. Perlakuan pada penelitian ini yaitu pengeringan cabai dengan blansing metode LTLT pada suhu $60^{\circ}, 70^{\circ}$, dan $80^{\circ} \mathrm{C}$ selama 20 menit. Sebagai pembanding, dilakukan juga pengeringan dengan perlakuan awal metode high temperature short time (HTST) blanching, pengeringan cabai tanpa perlakuan awal blansing di dalam alat pengering, serta pengeringan cabai tanpa perlakuan awal blansing di bawah sinar matahari secara langsung. Hasil penelitian menunjukkan bahwa cabai dengan perlakuan awal blansing, baik blansing metode LTLT maupun HTST, memiliki laju pengeringan yang lebih tinggi sehingga lebih cepat mencapai kadar air target dibandingkan dengan cabai tanpa perlakuan blansing. Warna cabai kering yang dihasilkan pada alat pengering juga lebih baik dari cabai kering yang dikeringkan langsung di bawah sinar matahari. Dari seluruh perlakuan yang melibatkan proses blansing, cabai dengan blansing metode LTLT pada suhu $80^{\circ} \mathrm{C}$ selama 20 menit merupakan perlakuan dengan laju pengeringan tercepat, dengan waktu pengeringan selama 34 jam, dan warna produk cabai kering yang menarik. Hasil evaluasi juga menunjukkan bahwa model Page adalah model yang paling sesuai untuk menggambarkan karakteristik pengeringan cabai dengan perlakuan awal blansing metode LTLT, dengan $\mathrm{R}^{2}$ berkisar antara 0.9913-0.9935, $\mathrm{X}^{2}$ berkisar antara 0.0005-0.0009, dan RSME berkisar antara 0.0221-0.0293.
\end{abstract}

Kata kunci: Blansing; cabai; model matematika; pengeringan; warna

(c) Penulis. Penerbit Universitas Pattimura. Akses terbuka dengan lisensi CC-BY-SA. 


\section{PENDAHULUAN}

Cabai merupakan komoditas pertanian dengan permintaan yang sangat tinggi. Akan tetapi harga cabai di pasaran cenderung berfluktuasi, yang disebabkan oleh kondisi hasil panen di tingkat petani. Harga cabai di pasaran selalu meningkat di musim penghujan, dimana terjadi kelangkaan cabai akibat gagal panen. Kegagalan panen tersebut disebabkan oleh banyaknya tanaman cabai yang membusuk akibat terlalu banyak menerima curah hujan. Namun ketika panen cabai melimpah, maka harga di pasaran cenderung menurun karena banyaknya pasokan cabai yang tersedia. Kondisi ini tentu saja sangat merugikan petani cabai yang mengharapkan untung besar saat panen raya. Dalam kondisi tersebut, petani terpaksa tetap harus menjual hasil panennya karena produk cabai segar tidak dapat disimpan dalam waktu lama. Cabai segar memiliki kadar air yang sangat tinggi yang dapat mencapai lebih dari $90 \%$, sehingga termasuk dalam golongan produk yang sangat mudah rusak dan tidak tahan lama (Ramdani et al., 2018).

Kerusakan dan pembusukan pada cabai segar dapat dicegah, salah satunya adalah dengan metode pengeringan. Proses pengeringan akan menurunkan kadar air sehingga cabai menjadi kering dan aman dari serangan jamur dan mikroorganisme pembusuk, serta tahan lama dalam penyimpanan. Keuntungan lain dari pengolahan cabai kering adalah jangkauan pemasaran produk yang jauh lebih luas karena sifat produknya yang lebih awet. Selain itu, produk cabai kering dapat menjadi alternatif pilihan saat terjadi kelangkaan cabai di pasaran akibat gagal panen di tingkat petani.

Permasalahan yang sering ditemukan pada produk cabai kering adalah warna yang kurang menarik. Hal ini perlu mendapat perhatian khusus karena warna cabai kering berperan penting sebagai salah satu indikator kualitas produk. Umumnya cabai yang dikeringkan akan berubah warna menjadi kecoklatan akibat terjadi reaksi pencoklatan. Reaksi pencoklatan dipicu oleh penggunaan suhu pengeringan yang tinggi, sehingga pemilihan jenis alat pengering akan sangat mempengaruhi proses pengeringan pada bahan.

Alat pengering tenaga surya memiliki keunggulan biaya operasionalnya yang murah dan kapasitasnya yang tinggi, serta dapat membantu menjaga kualitas warna. Hal ini seperti yang dilaporkan pada penelitian Cahyani (2011), yang menyatakan bahwa bahan yang dikeringkan dengan pengering tenaga surya tipe solar tunnel drying memiliki warna yang lebih baik jika dibandingkan dengan pengering kabinet.

Selain suhu, perlakuan awal sebelum pengeringan juga berpengaruh terhadap kualitas warna pada cabai kering. Perlakuan blansing pada bahan sebelum proses pengeringan berlangsung merupakan cara yang efektif untuk menghindari reaksi pencoklatan secara enzimatik maupun non enzimatik pada sayuran dan buah-buahan (Liu et al., 2019; Nalawade et al., 2018; Tao et al., 2019). Salah satu metode blansing yang belum banyak diterapkan untuk perlakuan awal pada pengeringan cabai adalah metode blansing yang dilakukan dengan suhu rendah dan dalam waktu yang cukup lama, atau yang dikenal dengan istilah low temperature long time (LTLT) blanching. Metode ini juga telah terbukti efektif memperbaiki kualitas hasil pengeringan produk pertanian, seperti yang dilaporkan dari hasil penelitian Silva et al. (2011) pada pengeringan labu, Choi (2014) pada pengeringan bawang, serta Asgar dan Musaddad (2008) pada pengeringan lobak.

Khusus untuk bahan cabai, masih perlu dilakukan penelitian untuk melihat pengaruh perlakuan awal blansing metode LTLT terhadap kualitas produk akhir, karena umumnya blansing pada cabai hanya dilakukan pada suhu tinggi dan dalam waktu yang singkat, yaitu pada kisaran suhu $90-100^{\circ} \mathrm{C}$ dan waktu 0,5-5 menit (Bodra dan Ansari, 2018; Murni dan Hartati, 2010; Tunde-Akintunde, 2010). Penelitian ini dilakukan dengan tujuan untuk mengetahui kinetika pengeringan cabai dengan perlakuan awal blansing suhu rendah waktu lama, terutama untuk mempelajari karakteristik pengeringannya, serta untuk mencari model matematika pengeringan yang paling sesuai.

\section{METODE PENELITIAN}

\section{Bahan dan Alat}

Bahan baku yang digunakan adalah cabai merah besar (Capsicum annuum L.). Cabai merah besar diperoleh langsung dari pengepul cabai, dengan jarak setelah panen adalah selama 1 hari setelah panen. Cabai tersebut kemudian langsung dilakukan blansing sesuai dengan jenis perlakuannya, dan selanjutnya dikeringkan. Proses pengeringan dilakukan menggunakan alat pengering tenaga surya tipe efek rumah kaca. Luas bangunan alat pengering adalah $150 \mathrm{~m}^{2}$, yang dilengkapi dengan 600 buah tray sebagai wadah bahan yang akan dikeringkan. 
Tabel 1. Enam variabel perlakuan teknologi pengeringan cabai

\begin{tabular}{|c|c|c|c|c|c|}
\hline \multirow{2}{*}{ No. } & \multirow{2}{*}{ Kode Sampel } & \multirow{2}{*}{ Cara Pengeringan } & \multicolumn{2}{|c|}{ Dengan Blansing } & \multirow{2}{*}{ Tanpa Blansing } \\
\hline & & & Suhu $\left({ }^{\circ} \mathrm{C}\right)$ & Lama & \\
\hline 1 & LTLT-60 & Alat pengering* & 60 & 20 menit & \\
\hline 2 & LTLT-70 & Alat pengering* & 70 & 20 menit & \\
\hline 3 & LTLT-80 & Alat pengering* & 80 & 20 menit & \\
\hline 4 & HTST & Alat pengering* & 100 & 15 detik & \\
\hline 5 & TB-P & Alat pengering* & & & Tanpa blansing \\
\hline 6 & TB-M & Sinar matahari langsung & & & Tanpa blansing \\
\hline
\end{tabular}

Keterangan: * $=$ alat pengering tenaga surya tipe efek rumah kaca

\section{Prosedur Penelitian}

Rancangan percobaan yang dilakukan yaitu Rancangan Acak Lengkap, dengan enam variabel perlakuan seperti terlihat pada Tabel 1. Tiga variabel pengeringan menggunakan alat pengering dengan perlakuan awal blansing pada suhu $60^{\circ}, 70^{\circ}$ dan $80^{\circ} \mathrm{C}$ selama 20 menit (kode sampel LTLT-60, LTLT-70, dan LTLT-80), satu variabel pengeringan menggunakan alat pengering dengan perlakuan awal blansing pada suhu $100^{\circ} \mathrm{C}$ selama 15 detik (kode sampel HTST), serta dua variabel pengeringan dengan alat pengering dan sinar matahari secara langsung tanpa perlakuan blansing (kode sampel TB-P dan TB-M).

Proses blansing dilakukan hanya menggunakan air dan tidak menambahkan natrium metabisulfit atau pun garam. Hal ini bertujuan untuk mengetahui pengaruh blansing metode LTLT maupun HTST terhadap cabai yang dikeringkan tanpa pengaruh dari bahan tambahan lain pada media blansing. Proses blansing dilakukan dengan cara memasukkan cabai ke dalam air pada suhu dan lama blansing sesuai dengan perlakuan yang tertera pada Tabel 1 .

Cabai yang akan dikeringkan terlebih dahulu dibersihkan, dicuci, ditiriskan, dan disortasi untuk memperoleh cabai dengan karakteristik sejenis. Cabai yang digunakan sebagai sampel pengeringan adalah cabai dengan bentuk utuh (tidak patah, tersayat, ataupun berlubang) dan keseluruhan buahnya berwarna merah. Selanjutnya cabai ditimbang sebanyak $500 \mathrm{~g}$ untuk tiap perlakuan, dan kemudian diberi perlakuan awal blansing sesuai dengan perlakuan masing-masing. Tahap selanjutnya adalah cabai dihamparkan di atas tray dalam satu lapisan tanpa tumpukan dan siap untuk dikeringkan.

Proses pengeringan dilakukan mulai pukul 9.00 hingga 16.00 setiap hari, dan proses pengeringan dihentikan jika massa cabai yang dikeringkan tidak lagi mengalami perubahan (konstan). Selama proses pengeringan berlangsung dilakukan pengamatan pada penurunan massa cabai menggunakan timbangan digital, iradiasi matahari menggunakan solar power meter, suhu pengeringan menggunakan termokopel dan data logger, kadar air, serta laju pengeringan. Parameter pengamatan diukur setiap 1 jam hingga pengeringan berakhir.

\section{Analisis Data}

\section{Warna}

Analisis warna dilakukan pada cabai setelah melalui proses blansing dan pada produk cabai kering. Pengukuran warna dilakukan dengan bantuan alat colorimeter. Nilai hasil pengukuran berupa nilai $L^{*}, a^{*}$, dan $b^{*}$. Pengukuran warna dilakukan pada tiap sampel cabai dalam satu perlakuan, dan kemudian nilainya dirata-ratakan.

\section{Kadar Air}

Kadar air diukur menggunakan metode AOAC (2012). Untuk menghitung kadar air basis basah dan basis kering digunakan persamaan sebagai berikut (Irfan et al., 2020; Lestari et al., 2020):

$$
\begin{gathered}
M=\frac{w(t)-d}{w(t)} \times 100 \% \\
X=\frac{w(t)-d}{d}
\end{gathered}
$$

Dimana $\mathrm{M}$ adalah kadar air basis basah (\%), $\mathrm{X}$ adalah kadar air basis kering ( $\mathrm{g}_{\text {air }} / \mathrm{g}_{\text {bahan kering }}$ ), d adalah massa kering bahan $(\mathrm{g})$, dan $\mathrm{w}(\mathrm{t})$ adalah massa bahan saat $\mathrm{t}(\mathrm{g})$.

\section{Laju Pengeringan}

Laju pengeringan merupakan banyaknya jumlah air yang menguap selama pengeringan berlangsung per satuan waktu. Laju pengeringan dihitung dengan persamaan sebagai berikut (Usman et al., 2020; Zakipour et al., 2011): 


$$
\mathrm{DR}=\frac{\mathrm{M}_{\mathrm{t}}-\mathrm{M}_{\mathrm{t}+\mathrm{dt}}}{\mathrm{d}_{\mathrm{t}}}
$$

Dimana: DR adalah laju pengeringan $\left(\mathrm{g}_{\text {air }} / \mathrm{g}_{\text {bahan }}\right.$ kering.jam), $\mathbf{M}_{\mathrm{t}}$ dan $\mathbf{M}_{\mathbf{t}+\mathrm{dt}}$ adalah kadar air basis kering saat $\mathrm{t}$ dan $\mathrm{t}+\mathrm{dt}$ ( $\mathrm{g}_{\text {air }} / \mathrm{g}_{\text {bahan kering }}$ ), serta $\mathrm{d}_{\mathrm{t}}$ adalah selang waktu pengeringan (jam).

\section{Moisture Ratio}

Moisture Ratio (MR) dapat dihitung menggunakan persamaan berikut (Fithriani et al., 2017; Garavand et al., 2011):

$$
\mathrm{MR}=\frac{\mathrm{M}_{\mathrm{t}}-\mathrm{M}_{\mathrm{e}}}{\mathrm{M}_{\mathrm{o}}-\mathrm{M}_{\mathrm{e}}}
$$

Dimana: MR adalah moisture ratio, $\mathrm{M}_{\mathrm{t}}$ adalah kadar air pada waktu yang ditentukan, $\mathrm{M}_{\mathrm{o}}$ adalah kadar air awal, dan $\mathrm{M}_{\mathrm{e}}$ adalah kadar air kesetimbangan.

\section{Model Matematika}

Model matematika dihitung berdasarkan data MR hasil percobaan. Data MR hasil percobaan kemudian dihubungkan terhadap waktu didalam grafik dan dihitung persamaan matematikanya hingga menghasilkan konstanta pengeringan $k, a$, dan $n$. Nilai $k, a$, dan $n$ hasil pemodelan digunakan untuk menghasilkan nilai MR model. Model matematika yang digunakan ditampilkan pada Tabel 2.

Indikator untuk menentukan kehandalan model persamaan terbaik dan sesuai dengan nilai eksperimental adalah koefisien determinasi $\left(\mathrm{R}^{2}\right)$, chi-square $\left(\chi^{2}\right)$, dan root mean square error (RMSE). Nilai $\mathrm{R}^{2}$ digunakan sebagai kriteria perbandingan untuk menentukan akurasi model (Borah et al., 2015). Nilai $\chi^{2}$ digunakan untuk menguji hubungan atau pengaruh antara variabel (Mazandarani et al., 2017). Nilai RMSE adalah penyimpangan antara nilai prediksi model dan nilai hasil eksperimen (Doymaz, 2012).

$$
\mathrm{R}^{2}=\frac{\sum_{\mathrm{i}=1}^{\mathrm{N}}\left(\mathrm{MR}_{\mathrm{i}}-\mathrm{MR}_{\mathrm{pre}, \mathrm{i}}\right) \cdot \sum_{\mathrm{i}=1}^{\mathrm{N}}\left(\mathrm{MR}_{\mathrm{i}}-\mathrm{MR}_{\mathrm{exp}, \mathrm{i}}\right)}{\sqrt{\left[\sum_{\mathrm{i}=1}^{\mathrm{N}}\left(\mathrm{MR}_{\mathrm{i}}-\mathrm{MR}_{\mathrm{pre}, \mathrm{i}}\right)^{2}\right] \cdot\left[\sum_{\mathrm{i}=1}^{\mathrm{N}}\left(\mathrm{MR}_{\mathrm{i}}-\mathrm{MR}_{\text {exp }, \mathrm{i}}\right)^{2}\right]}}
$$

$$
\begin{gathered}
\chi^{2}=\frac{\sum_{\mathrm{i}=1}^{\mathrm{n}}\left(\mathrm{MR}_{\mathrm{exp}, \mathrm{i}}-\mathrm{MR}_{\mathrm{pre}, \mathrm{i}}\right)^{2}}{\mathrm{~N}-\mathrm{z}} \\
\mathrm{RMSE}=\sqrt{\frac{\sum_{\mathrm{i}=1}^{\mathrm{n}}\left(\mathrm{MR}_{\mathrm{pre}, \mathrm{i}}-M R_{\text {exp }, \mathrm{i}}\right)^{2}}{N}}
\end{gathered}
$$

Dimana: $\mathrm{MR}_{\text {pre,i }}$ adalah MR yang diprediksi, $\mathrm{MR}_{\text {exp,i }}$ adalah MR eksperimental, $\mathrm{N}$ adalah jumlah pengamatan, dan $\mathrm{n}$ adalah jumlah konstanta.

\section{HASIL DAN PEMBAHASAN}

\section{Suhu dan Radiasi Matahari}

Suhu pengeringan pada alat pengering tenaga surya tipe efek rumah kaca sangat ditentukan oleh intensitas penyinaran matahari. Hal ini menyebabkan suhu udara pengering selama proses pengeringan berlangsung sangat berfluktuasi, seperti ditampilkan pada Gambar 1. Hasil ini juga sejalan dengan penelitian Phang et al. (2015) dan Irfan et al. (2020) yang menyatakan bahwa efek penyinaran matahari merupakan hal yang sangat vital dan signifikan pada pengering surya. Suhu pada ruang pengering biasanya akan mencapai suhu tertinggi pada pukul 12.00 13.00, atau pada saat puncak radiasi matahari. Suhu pengeringan ini akan lebih maksimal jika tidak terdapat tutupan awan yang dapat mengganggu penyinaran matahari.

Proses pengeringan ini akan berjalan lebih efektif jika dilakukan pada kondisi cuaca yang mendukung. Semakin tinggi intensitas penyinaran matahari maka akan semakin tinggi juga suhu pada ruang pengering. Saat suhu udara ruang pengering meningkat, maka penguapan air dari bahan juga akan meningkat. Hal ini juga sejalan dengan hasil penelitian Usman et al. (2020), Lestari et al. (2020), Santoso et al. (2018) dan Omolola et al. (2015) yang menyatakan bahwa kemampuan bahan untuk melepaskan air dari permukaan akan semakin besar dengan meningkatnya suhu udara di ruang pengering.

Tabel 2. Model matematika yang digunakan untuk menggambarkan pengeringan lapis tipis

\begin{tabular}{llll}
\hline \multicolumn{1}{c}{ Model } & & Persamaan & \multicolumn{1}{c}{ Referensi } \\
\hline Page & $\mathrm{MR}=\exp \left(-\mathrm{kt}^{\mathrm{n}}\right)$ & $\ln (-\ln (\mathrm{MR}))=\ln (\mathrm{k})+\mathrm{n} \ln (\mathrm{t})$ & $\begin{array}{l}\text { Ganesapillai } \text { et al. (2011); Akoy } \\
(2014)\end{array}$ \\
Lewis & $\mathrm{MR}=\exp (-\mathrm{kt})$ & $\ln (\mathrm{MR})=-\mathrm{kt}$ & $\begin{array}{l}\text { Fithriani } \text { et al. } \text { (2017); Zakipour } \text { et } \\
\text { al. }(2011)\end{array}$ \\
$\begin{array}{l}\text { Henderson } \\
\text { and Pabis }\end{array}$ & $\mathrm{MR}=\mathrm{a} \exp (-\mathrm{kt})$ & $\ln (\mathrm{MR})=-\mathrm{kt}+\ln (\mathrm{a})$ & $\begin{array}{l}\text { Omolola } \text { et al. } \text { (2015); Hashim } \text { et al. } \\
(2014)\end{array}$ \\
\hline
\end{tabular}




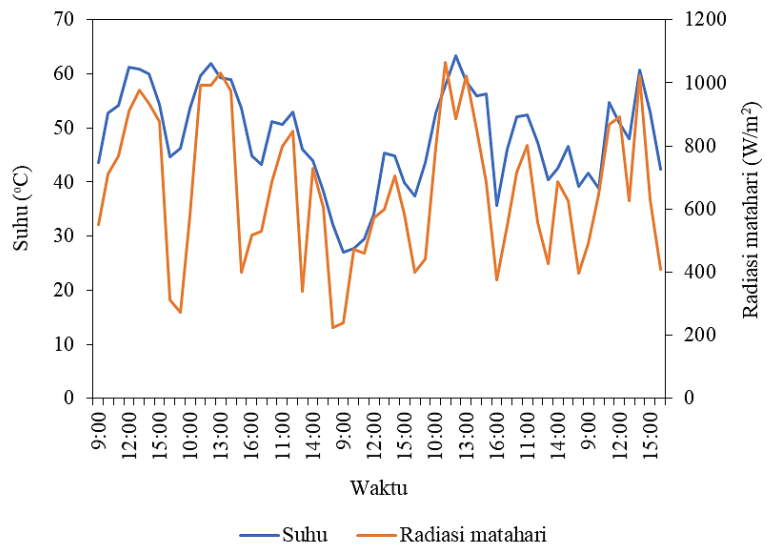

Gambar 1. Hubungan antara suhu pengeringan dan radiasi matahari

\section{Karakteristik Pengeringan}

\section{Kadar Air}

Kadar air merupakan salah satu indikator penentu kualitas cabai kering. Cabai kering hendaknya memiliki kadar air yang rendah agar awet dan tahan lama dalam penyimpanan. Cabai yang dikeringkan pada penelitian ini seluruhnya telah mencapai kadar air yang sesuai standar SNI 01-3389-1994, yaitu maksimal $11 \%$. Kadar air terendah yang dicapai oleh semua perlakuan adalah sebesar $8,66 \%$. Akan tetapi untuk mencapai kadar air tersebut diperlukan waktu pengeringan yang berbeda-beda pada tiap perlakuan. Perlakuan dengan perlakuan awal blansing pada suhu $80^{\circ} \mathrm{C}$ selama 20 menit (LTLT-80) adalah yang tercepat mencapai kadar air kesetimbangan, yaitu selama 34 jam pengeringan, yang diikuti oleh perlakuan HTST selama 37 jam, LTLT-70 selama 38 jam, LTLT-60 selama 40 jam, serta yang terlama adalah perlakuan TB-P dan TB-M selama 47 jam. Penurunan kadar

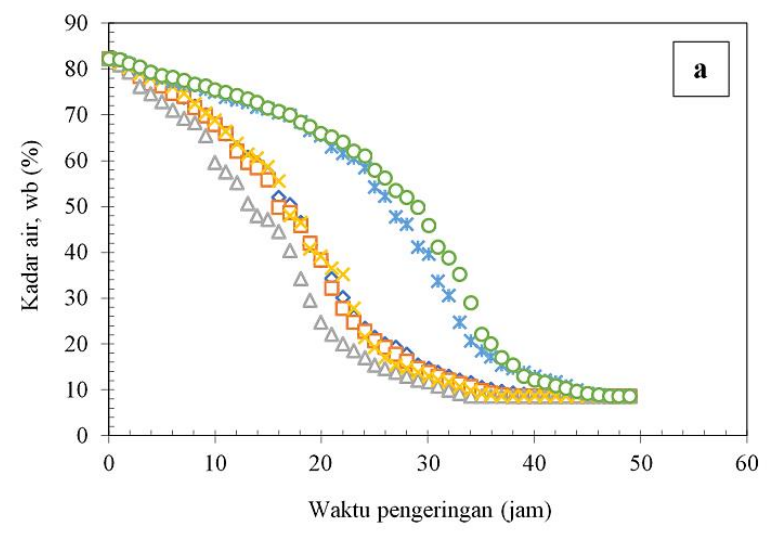

$\diamond$ LTLT-60 $\square$ LTLT-70 $\triangle$ LTLTL-80 $\times$ HTST $\quad *$ TB-P OTB-M air selama proses pengeringan berlangsung ditampilkan pada Gambar 2.

Kecepatan penurunan kadar air erat kaitannya dengan suhu udara pengering dan cara blansing. Selain suhu, kecepatan penurunan kadar air ini juga sangat dipengaruhi oleh perlakuan awal blansing. Cabai dengan perlakuan blansing lebih cepat kering dibandingkan dengan tanpa blansing. Hal ini sejalan dengan hasil penelitian Rocha et al. (1993) yang menyatakan bahwa blansing berguna untuk meningkatkan permeabilitas dinding sel, sehingga mendukung air untuk lebih mudah berpindah ke permukaan dan kemudian mening-galkan bahan. Jika dibandingkan antara kecepatan penurunan kadar air pada perlakuan LTLT dan HTST, maka tidak terlihat perbedaan yang sangat mencolok. Hal ini membuktikan bahwa semua metode blansing efektif untuk mempercepat pengeringan. Namun kombinasi antara metode dan waktu blansing yang tepat akan menghasilkan waktu pengeringan yang lebih cepat, seperti pada perlakuan LTLT-80.

\section{Laju Pengeringan}

Grafik laju pengeringan yang ditampilkan pada Gambar 3 menunjukkan banyaknya pelepasan uap air per satuan waktu yang sangat bervariasi dan berfluktuasi. Variasi dan fluktuasi ini disebabkan oleh kondisi operasi pengeringan serta sifat bahan yang dikeringkan. Kondisi operasi pengeringan seperti suhu udara pengering, kelembaban udara, dan aliran udara akan mempengaruhi laju pelepasan air dari permukaan bahan. Suhu pengeringan yang lebih tinggi menghasilkan laju pengeringan yang lebih tinggi dan akibatnya kadar air menurun lebih cepat (Akoy, 2014).

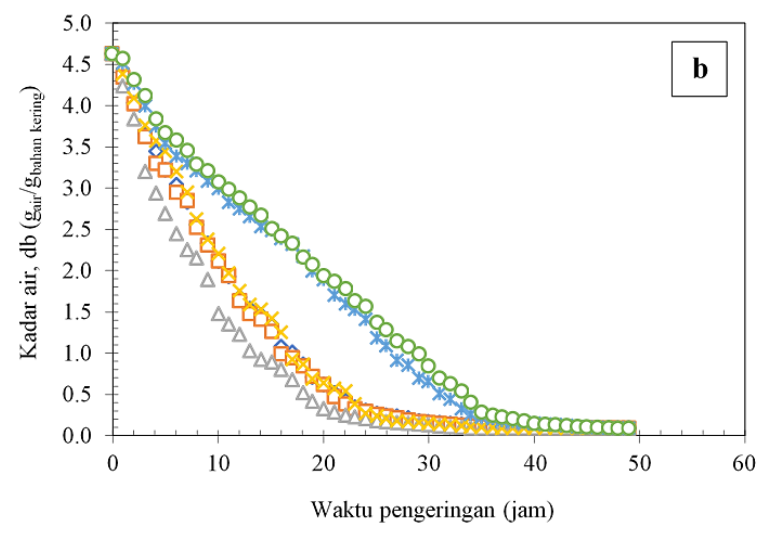

$\diamond$ LTLT-60 $\quad$ LLTLT-70 $\triangle$ LTLTL-80 $\quad \times$ HTST $\quad *$ TB-P OTB-M

Gambar 2. Hubungan antara kadar air terhadap waktu pengeringan: a) kadar air basis basah, dan b) kadar air basis kering 
Kelembaban udara berpengaruh terhadap proses pemindahan uap air. Apabila kelembaban udara rendah, maka perbedaan tekanan uap di dalam dan di luar bahan menjadi besar, sehingga mempercepat pemindahan uap air dari dalam bahan menuju permukaan. Kelembaban udara ini berhubungan dengan suhu, dimana suhu pengeringan yang tinggi akan menurunkan kelembaban udara di ruang pengering. Laju aliran udara pada alat pengering yang digunakan adalah hasil kerja dari kipas di langit-langit ruang pengering. Kipas tersebut berfungsi menggerakkan udara agar suhu lebih seragam di semua titik pada ruang pengering, dan juga sekaligus memberi efek aliran udara untuk meningkatkan laju pengeringan.

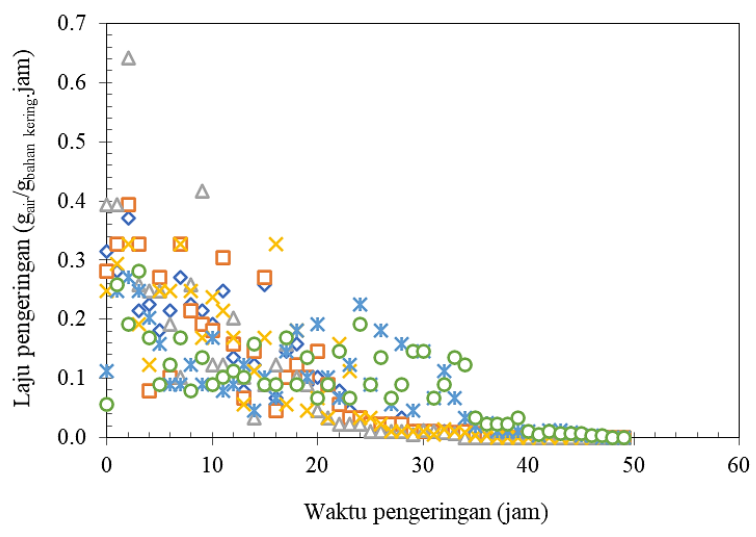

$\diamond$ LTLT-60 $\quad$ LLTLT-70 $\triangle$ LTLTL-80 $\times$ HTST $*$ TB-P $\quad$ OTB-M

Gambar 3. Hubungan antara laju pengeringan
terhadap waktu

Gambar 3 dan 4 juga menunjukkan bahwa semakin lama waktu pengeringan, maka laju pengeringan akan semakin menurun. Hal ini disebabkan karena sebagian besar air bebas pada bahan telah menguap di awal proses pengeringan, dan sisanya merupakan air terikat yang sukar untuk berdifusi ke permukaan bahan. Fenomena ini menggambarkan karakteristik khas pengeringan bahan pertanian yang disebut periode laju menurun, yang diindikasikan oleh lambatnya proses difusi air dalam bahan di tahap akhir pengeringan. Pada tahap akhir proses pengeringan, air terikat yang tersisa dalam bahan membutuhkan waktu lebih lama untuk berdifusi ke permukaan sehingga menyebabkan penurunan laju pengeringan. Waktu penurunan laju pengeringan tersebut beragam untuk tiap perlakuan, namun umumnya pada penelitian ini laju pengeringan menurun setelah 20 jam pengeringan. Fenomena penurunan laju pengeringan ini juga terjadi pada bahan pertanian lainnya, seperti yang dilaporkan dari penelitian Lestari et al. (2020) pada pengeringan jahe merah, Syam et al. (2019) pada pengeringan kunyit, Santoso et al. (2018) pada pengeringan kopi, Suhendar et al. (2017) pada pengeringan sukun, serta Rozana et al. (2016) pada pengeringan mangga.

Perlakuan awal blansing juga sangat berperan dalam mempercepat laju pengeringan. Cabai dengan perlakuan blansing (LTLT-60, LTLT-70, LTLT-80, dan HTST), memiliki laju pengeringan yang lebih tinggi dibandingkan dengan tanpa blansing (TB-P dan TB-M). Hal ini terjadi karena blansing dapat mengurangi resistensi terhadap pergerakan uap air yang berefek pada peningkatan laju pengeringan (Hossain et al., 2007). Dengan demikian blansing baik diterapkan untuk mempersingkat waktu pengeringan cabai.

\section{Warna}

Perubahan warna pada cabai setelah proses blansing (sebelum pengeringan) dan setelah proses pengeringan ditampilkan pada Gambar 5. Dari Gambar 5a terlihat bahwa cabai dengan perlakuan blansing (LTLT-60, LTLT-70, LTLT-80, dan HTST) umumnya akan mengalami peningkatan nilai $L^{*}, a^{*}$, dan $b^{*}$ jika dibandingkan dengan cabai tanpa blansing (TB-P dan TB-M). Sedangkan pada produk cabai kering (Gambar 5 b), nilai $L^{*}, a^{*}$, dan $b^{*}$ pada perlakuan LTLT-60, LTLT-70, LTLT-80, dan HTST menurun jauh dari kondisi awalnya, dan juga lebih rendah dari perlakuan TB-P dan TB-M. Perubahan warna selama blansing disebabkan karena cabai mendapatkan penambahan air dari pengenceran padatan. Hal tersebut mengurangi terjadinya reaksi pencoklatan karena air akan menurunkan interaksi antara asam amino dan gula (Niartika, 2018). Sedangkan pada produk cabai kering nilai $L^{*}, a^{*}$, dan $b^{*}$ pada perlakuan LTLT60, LTLT-70, LTLT-80, dan HTST cenderung menurun karena senyawa karotenoid yang menyebabkan warna merah pada cabai tersebut sangat sensitif terhadap udara, sinar, dan suhu tinggi saat proses pengeringan (Dutta et al., 2004).

Warna cabai kering yang diberi perlakuan blansing memiliki nilai $L^{*}, a^{*}$, dan $b^{*}$ yang lebih rendah dari cabai tanpa blansing dikarenakan cabai dengan perlakuan blansing lebih dahulu kering dan mencapai kadar air kesetimbangan sebelum batas waktu pengeringan berakhir. Proses pengeringan sendiri dihentikan secara serentak ketika semua perlakuan sudah mencapai kadar air kesetimbangan atau kadar air sebesar $8,66 \%$. 

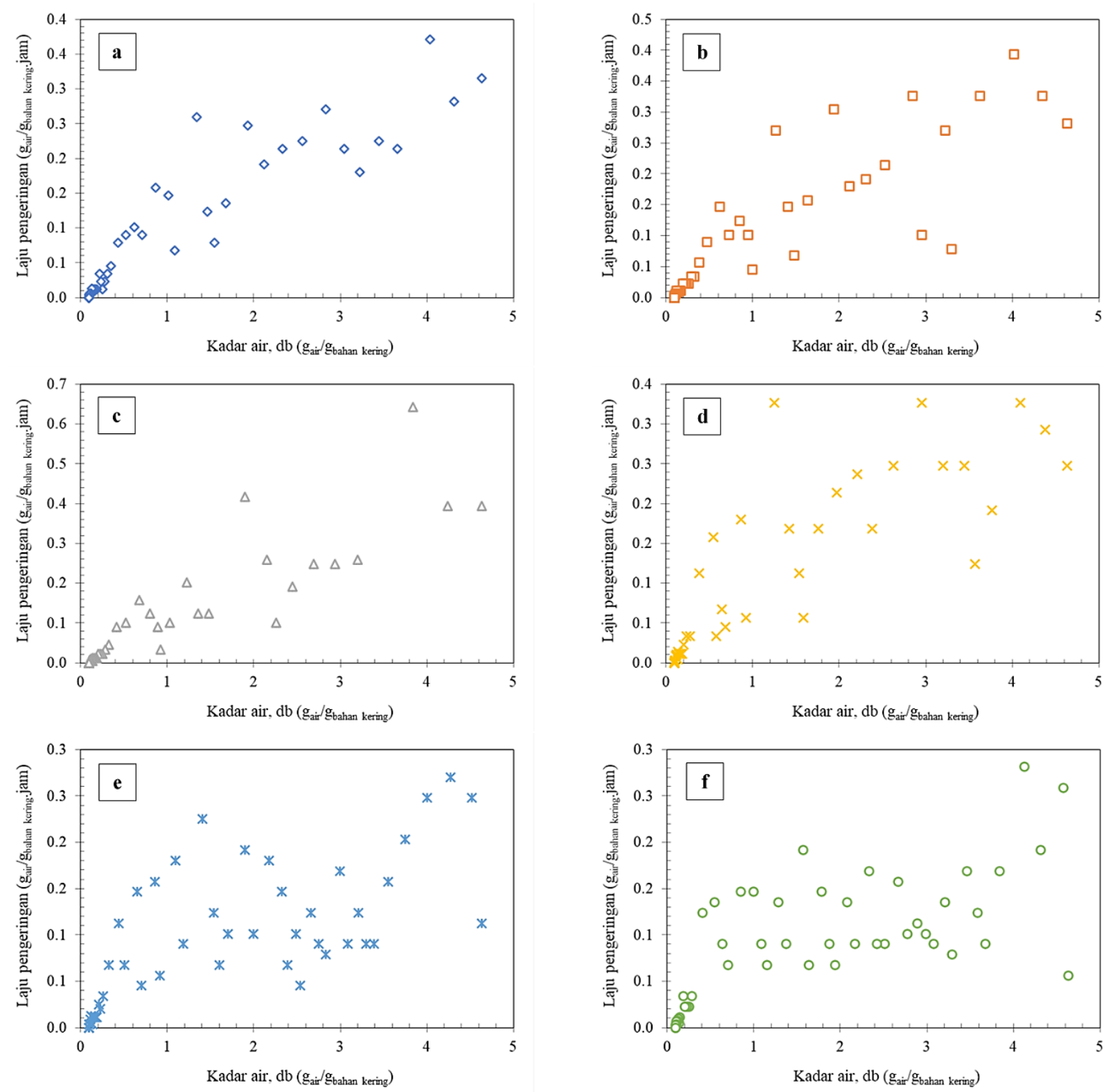

Gambar 4. Hubungan antara laju pengeringan dan kadar air basis kering pada tiap perlakuan: a) LTLT-60, b) LTLT-70, c) LTLT-80, d) HTST, e) TB-P, dan f) TB-M

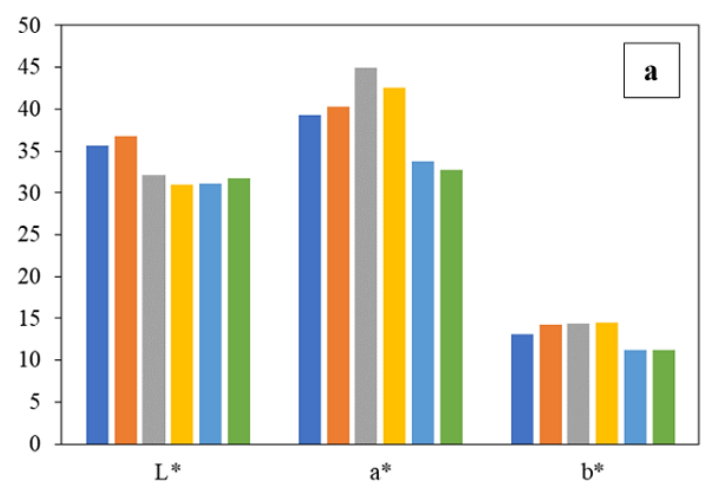

- LTLT-60 $=$ LTLT-70 $=$ LTLT-80 $=$ HTST $=$ TB-P $=$ TB-M

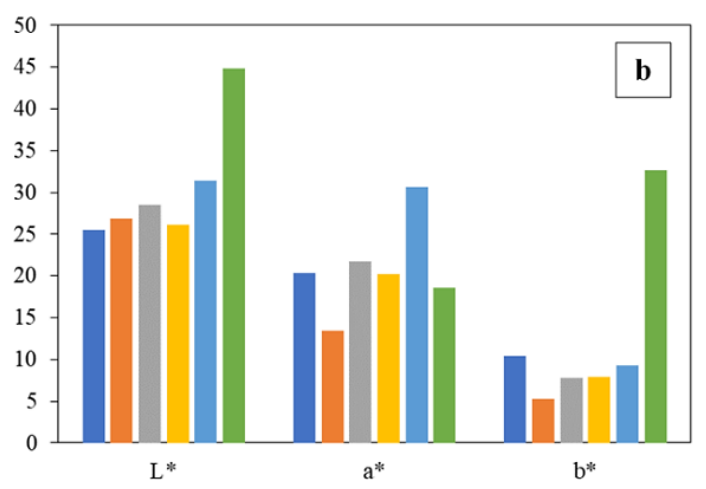

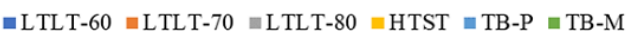

Gambar 5. Analisis warna cabai: a) setelah blansing, dan b) setelah pengeringan berakhir 
Proses pengeringan berakhir saat perlakuan TB-P dan TB-M telah mencapai kadar air kesetimbangan, karena kedua perlakuan ini adalah yang terlama mencapai kadar air kesetimbangan. Hal ini menyebabkan cabai pada perlakuan LTLT-60, LTLT-70, LTLT-80, dan HTST yang telah terlebih dahulu mencapai kadar air kesetimbangan masih tetap mengalami proses pengeringan (masih menerima panas), sehingga mengalami degradasi akibat sensitifitas karotenoid terhadap udara, sinar, dan suhu tinggi.

Hal inilah yang terjadi pada cabai kering dengan perlakuan LTLT-60, LTLT-70, LTLT-80, dan HTST sehingga seolah-olah warnanya tidak lebih baik dari perlakuan TB-P. Cabai dengan perlakuan LTLT-60, LTLT-70, LTLT-80, dan HTST apabila proses pengeringannya langsung dihentikan setelah mencapai kadar air kesetimbangan, maka warna yang dihasilkan diduga akan jauh lebih baik dari perlakuan TB-P, karena waktu pengeringannya lebih singkat, yang berarti waktu pemanasan yang dapat mendegradasi karotenoidnya pun lebih singkat. Dengan demikian maka cabai yang telah mencapai kadar air target sebaiknya langsung dihentikan proses pengeringannya dan selanjutnya dikemas.

Namun dengan segala permasalahan tersebut, cabai kering dari perlakuan LTLT-60, LTLT-70, LTLT-80, dan HTST tetap memiliki warna yang menarik, dengan warna merah pekat, kulit yang transparan, dan mengkilap. Tampilan fisik inipun tidak terlalu jauh berbeda dengan cabai pada perlakuan TB-P yang kecerahan warnanya sedikit diatas dari cabai-cabai dengan perlakuan awal blansing. Akan tetapi pada perlakuan TB-M cabai kering yang dihasilkan cenderung berwarna kuning kecokelatan dengan warna kulit yang kusam. Hal ini disebabkan karena cabai dikeringkan langsung dibawah sinar matahari, sehingga tidak dapat menjaga sensitifitas karotenoid cabai dari udara, sinar matahari, dan suhu tinggi.

\section{Model Matematika}

Rasio kelembaban atau moisture ratio (MR) merupakan variabel fungsi yang berhubungan dengan kadar air awal, kadar air kesetimbangan, serta kadar air pada waktu aktual tertentu. Kurva hubungan antara MR terhadap waktu pengeringan dapat menggambarkan karakteristik dari pengeringan cabai. Sama halnya seperti laju pengeringan dan kadar air, nilai MR juga mengalami penurunan selama proses pengeringan berlangsung seperti yang ditampilkan pada Gambar 6. Kurva penurunan nilai MR ini selanjutnya dianalisis dan dievaluasi dengan tiga model matematika pengeringan lapisan tipis.

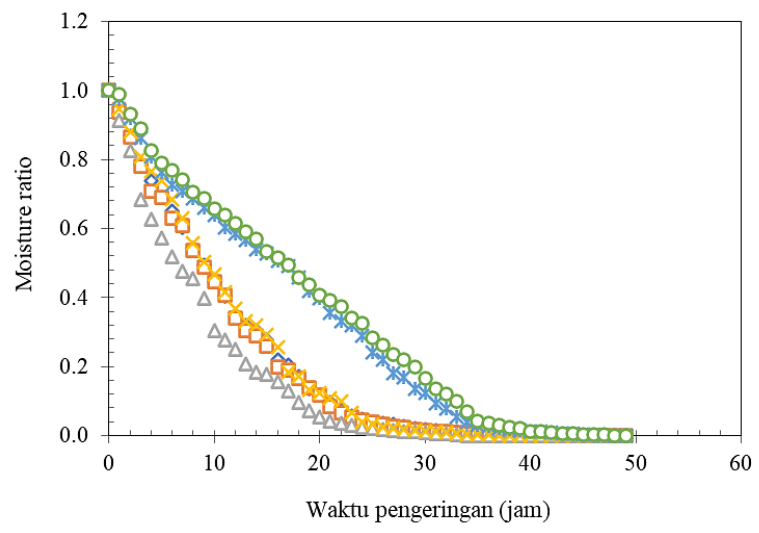

$\diamond$ LTLT-60 ㄴLTLT-70 $\triangle$ LTLTL-80 $\times$ HTST $*$ TB-P OTB-M

Gambar 6. Hubungan antara MR eksperimental terhadap waktu pengeringan

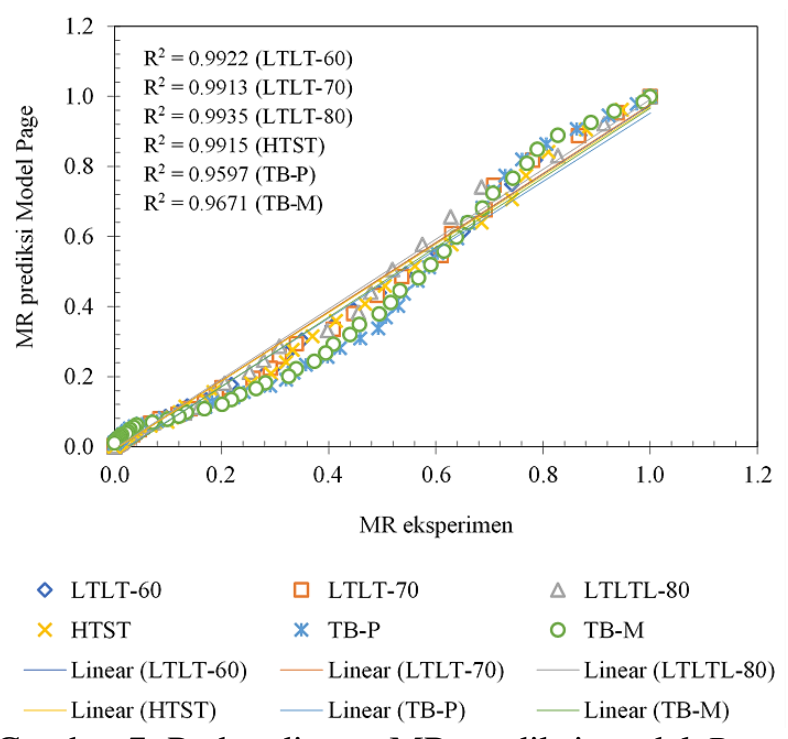

Gambar 7. Perbandingan MR prediksi model Page dengan MR hasil eksperimental

Hasil evaluasi menunjukkan bahwa model Page adalah model yang paling sesuai untuk menggambarkan karakteristik pengeringan cabai dengan metode lapisan tipis untuk semua perlakuan. Jika dibandingkan lebih teliti dari hasil analisis keabsahan pada Tabel 4, maka kesesuaian perlakuan dengan blansing metode LTLT sedikit lebih tinggi dari perlakuan lainnya. Model Page dipilih sebagai model yang paling sesuai karena secara umum hasil evaluasinya menunjukkan tingkat kesesuaian paling tinggi dari perbandingan MR yang diprediksi dan MR hasil eksperimen dibandingkan dengan model-model lainnya (Gambar 7 dan Tabel 4). Tingkat kesesuaian ini 
dibuktikan dengan nilai $\mathrm{R}^{2}$ yang berkisar antara 0.9597-0.9935 yang artinya akurasi model sangat sesuai, serta $\chi^{2}$ yang berkisar antara 0.0005-0.0050 yang berarti adanya hubungan atau pengaruh antara variabel, serta RMSE yang berkisar antara 0.02210.0703 yang berarti bahwa penyimpangan antara nilai prediksi model dan nilai hasil eksperimennya sangat rendah (Tabel 4). Semakin tinggi nilai $\mathrm{R}^{2}$ mendekati 1 dan semakin rendah nilai $\chi^{2}$ dan RMSE mendekati 0, maka tingkat kesesuaian model tersebut semakin tinggi (Prasetyo et al., 2018; Fithriani et al., 2017; Omolola et al., 2015; Meisamiasl et al., 2010). Konstanta-konstanta pengeringan hasil evaluasi ditampilkan pada Tabel 3.

Tabel 3. Nilai konstanta dan koefisien pengeringan cabai dari masing-masing model

\begin{tabular}{clcccl}
\hline Model & Perlakuan & $a$ & $k$ & $n$ & Persamaan \\
\hline \multirow{5}{*}{ Page } & LTLT-60 & & 0,0482 & 1,2909 & $\ln [-\ln (\mathrm{MR})]=\ln (0,0482)+1,2909 \ln (\mathrm{t})$ \\
& LTLT-70 & & 0,0481 & 1,3019 & $\ln [-\ln (\mathrm{MR})]=\ln (0,0481)+1,3019 \ln (\mathrm{t})$ \\
& LTLT-80 & & 0,0813 & 1,1863 & $\ln [-\ln (\mathrm{MR})]=\ln (0,0813)+1,1863 \ln (\mathrm{t})$ \\
& HTST & & 0,0382 & 1,3709 & $\ln [-\ln (\mathrm{MR})]=\ln (0,0382)+1,3709 \ln (\mathrm{t})$ \\
& TB-P & & 0,0213 & 1,3877 & $\ln [-\ln (\mathrm{MR})]=\ln (0,0213)+1,3877 \ln (\mathrm{t})$ \\
& TB-M & & 0,0156 & 1,4568 & $\ln [-\ln (\mathrm{MR})]=\ln (0,0156)+1,4568 \ln (\mathrm{t})$ \\
\hline \multirow{5}{*}{ Lewis } & LTLT-60 & & 0,1429 & & $\ln (\mathrm{MR})=-0,1429 \mathrm{t}$ \\
& LTLT-70 & & 0,1475 & & $\ln (\mathrm{MR})=-0,1475 \mathrm{t}$ \\
& LTLT-80 & & 0,1594 & & $\ln (\mathrm{MR})=-0,1594 \mathrm{t}$ \\
& HTST & & 0,1499 & & $\ln (\mathrm{MR})=-0,1499 \mathrm{t}$ \\
& TB-P & & 0,1027 & & $\ln (\mathrm{MR})=-0,1027 \mathrm{t}$ \\
TB-M & & 0,0965 & & $\ln (\mathrm{MR})=-0,0965 \mathrm{t}$ \\
\hline \multirow{5}{*}{ Pabis } & LTLT-60 & 2,0974 & 0,1653 & & $\ln (\mathrm{MR})=-0,1653 \mathrm{t}+\ln (2,0974)$ \\
& LTLT-70 & 2,0776 & 0,1696 & & $\ln (\mathrm{MR})=-0,1696 \mathrm{t}+\ln (2,0776)$ \\
& LTLT-80 & 1,4326 & 0,1703 & & $\ln (\mathrm{MR})=-0,1703 \mathrm{t}+\ln (1,4326)$ \\
& HTST & 2,2291 & 0,1742 & & $\ln (\mathrm{MR})=-0,1742 \mathrm{t}+\ln (2,2291)$ \\
& TB-P & 3,0042 & 0,1360 & & $\ln (\mathrm{MR})=-0,1360 \mathrm{t}+\ln (3,0042)$ \\
& TB-M & 3,0192 & 0,1300 & & $\ln (\mathrm{MR})=-0,1300 \mathrm{t}+\ln (3,0192)$ \\
\hline
\end{tabular}

Tabel 4. Analisis keabsahan model pengeringan cabai

\begin{tabular}{cllll}
\hline Model & \multicolumn{1}{c}{ Perlakuan } & $\mathrm{R}^{2}$ & $\mathrm{X}^{2}$ & RMSE \\
\hline \multirow{3}{*}{ Page } & LTLT-60 & 0,9922 & 0,0008 & 0,0283 \\
& LTLT-70 & 0,9913 & 0,0009 & 0,0293 \\
& LTLT-80 & 0,9935 & 0,0005 & 0,0221 \\
& HTST & 0,9915 & 0,0010 & 0,0309 \\
& TB-P & 0,9597 & 0,0050 & 0,0703 \\
& TB-M & 0,9671 & 0,0043 & 0,0649 \\
\hline \multirow{2}{*}{ Lewis } & LTLT-60 & 0,9389 & 0,0113 & 0,1051 \\
& LTLT-70 & 0,9362 & 0,0115 & 0,1060 \\
& LTLT-80 & 0,9709 & 0,0042 & 0,0638 \\
& HTST & 0,9176 & 0,0160 & 0,1253 \\
& TB-P & 0,8621 & 0,0318 & 0,1765 \\
& TB-M & 0,8673 & 0,0339 & 0,1822 \\
\hline \multirow{2}{*}{ Henderson and Pabis } & LTLT-60 & 0,9031 & 0,0574 & 0,2372 \\
& LTLT-70 & 0,9013 & 0,0543 & 0,2307 \\
& LTLT-80 & 0,9601 & 0,0081 & 0,0890 \\
& HTST & 0,8754 & 0,0689 & 0,2599 \\
& TB-P & 0,7740 & 0,2552 & 0,5001 \\
& TB-M & 0,7750 & 0,2645 & 0,5092 \\
\hline
\end{tabular}




\section{KESIMPULAN}

Hasil penelitian diperoleh kesimpulan bahwa perlakuan awal blansing dengan suhu rendah dengan waktu lama memberi pengaruh positif pada pengeringan cabai, yaitu meningkatkan laju pengeringan, mempercepat waktu pengeringan, serta menghasilkan warna cabai kering yang menarik. Hasil evaluasi menunjukkan bahwa model Page adalah model yang paling sesuai untuk menggambarkan karakteristik pengeringan cabai dengan perlakuan awal blansing LTLT, dengan $\mathrm{R}^{2}$ berkisar antara $0.9913-0.9935, \mathrm{X}^{2}$ berkisar antara 0.0005-0.0009, dan RSME berkisar antara 0.02210.0293 . Perlakuan terbaik yaitu pengeringan cabai dengan perlakuan blansing LTLT pada suhu $80{ }^{\circ} \mathrm{C}$ selama 20 menit, dan pengeringan dengan alat pengering selama 34 jam. Cabai yang dihasilkan memiliki warna yang menarik dan tingkat keabsahan kesesuaian model yang tertinggi.

\section{UCAPAN TERIMA KASIH}

Ucapan terima kasih ditujukan kepada Universitas Negeri Makassar yang telah memberikan bantuan biaya penelitian melalui program PNBP 2020 sehingga penelitian ini dapat terlaksana dengan baik.

\section{DAFTAR PUSTAKA}

Akoy, E.O.M. 2014. Experimental characterization and modeling of thin-layer drying of mango slices. International Food Research Journal 21: 1911-1917.

[AOAC] Association of Official Analytical Chemists. 2012. Official Methods of Analysis of The Association of Official Analytical Chemists. AOAC Inc. Arlington, Virginia.

Asgar, A., dan D. Musaddad. 2008. Pengaruh media, suhu, dan lama blansing sebelum pengeringan terhadap mutu lobak kering. Jurnal Hortikultura 18: 87-94.

Bodra, N., and I.A. Ansari. 2018. Optimization of blanching treatments of green chilli. International Journal of Chemical Studies 6: 486-489.

Borah, A., K. Hazarika, and S.M. Khayer. 2015. Drying kinetics of whole and sliced turmeric rhizomes (Curcuma longa L.) in a solar conduction dryer. Information Processing in Agriculture 2: 85-92. DOI: 10.1016/j.inpa. 2015.06.002
Cahyani, D.W. 2011. Pengaruh Tiga Metode Pengeringan (Cabinet Drying, Solar Tunnel Drying, dan Freeze Drying) Terhadap Warna, Kandungan Beta Karoten Serta Tingkat Kesukaan Konsumen Pada Cabai Merah Besar Panjang. Skripsi. Semarang: Fakultas Teknologi Pertanian, Universitas Katolik Soegijapranata.

Choi, J.B. 2014. Prevention of tissue softening of retorted onion by long time, low temperature blanching in calcium solution. Culinary Science and Hospitality Research 20: 54-64.

Doymaz, İ. 2012. Evaluation of some thin-layer drying models of persimmon slices (Diospyros kaki L.). Energy Conversion and Management 56: 199-205. DOI: 10.1016/j. enconman.2011.11.027

Dutta, D., U. Raychaudhuri, and R. Chakraborty. 2004. Retention of $\beta$-carotene in frozen carrots under frying condition of temperature and time of storage. African Journal of Biotechnology 4: 102-108.

Fithriani, D., L. Assadad, dan Z. A. Siregar. 2017. Karakteristik dan model matematika kurva pengeringan rumput laut Eucheuma cottonii. Jurnal Pascapanen dan Bioteknologi Kelautan dan Perikanan 11: 159-170. DOI: 10.15578/jpbkp.v11i2.290

Ganesapillai, M., I. Regupathi, and T. Murugesan. 2011. Modelling of thin layer drying of banana (Nendran spp.) under microwave, convective and combined microwaveconvective processes. Chemical Product and Process Modeling 6: 1-27. DOI: 10.2202/ 1934-2659.1479

Garavand, A.T., S. Raffiee, and A. Keyhani. 2011. Mathematical modelling of thin layer drying kinetics of tomato influence of air dryer conditions. International Transaction Journal of Engineering, Management, Applied Sciences, and Technologies 2: 147160.

Hashim, N., O. Daniel, and E. Rahaman. 2014. A preliminary study: kinetic model of drying process of pumpkins (Cucurbita moschata) in a convective hot air dryer. Agriculture and Agricultural Science Procedia 2: 345-352. DOI: 10.1016/j.aaspro.2014.11.048

Hossain, M. A., J. L. Woods, and B. K. Bala. 2007. Single-layer drying characteristics and colour kinetics of red chilli. International Journal of Food Science and Technology 42: 13671375. DOI: $10.1111 / \mathrm{j} .1365-2621.2006$. 01414.x 
Irfan, A.M., A. Arimansyah, A.R. Rasyid, dan N. Lestari. 2020. Unjuk kerja pengering tenaga surya tipe efek rumah kaca untuk pengeringan cabai dengan perlakuan low temperature long time blanching. Rona Teknik Pertanian 13: 42-58. DOI: 10.17969/rtp.v13i2.17788

Lestari, N., R. Fadilah, A.M.A. Mukhlis, dan S. Samsuar. 2020. Efek perlakuan low temperature long time blanching terhadap karakteristik cabai kering. Agrika 14: 140156. DOI: $10.31328 /$ ja.v14i2.1619

Lestari, N., S. Samsuar, E. Novitasari, dan K. Rahman. 2020. Kinerja cabinet dryer pada pengeringan jahe merah dengan memanfaatkan panas terbuang kondensor pendingin udara. Jurnal Agritechno 13: $57-$ 70. DOI: 10.20956/at.v13i1.250

Liu, Z.L., J.W. Bai, W.X. Yang, J. Wang, L.Z. Deng, X.L. Yu, Z.A. Zheng, Z.J. Gao, and H. W. Xiao. 2019. Effect of high-humidity hot air impingement blanching (HHAIB) and drying parameters on drying characteristics and quality of broccoli florets. Drying Technology 37: 1251-1264. DOI: 10.1080/ 07373937.2018.1494185

Mazandarani, Z., N. Aghajani, A.D. Garmakhany, M.J.B. Ardalan, and M. Nouri. 2017. Mathematical modeling of thin layer drying of pomegranate (Punica granatum L.) arils: various drying methods. Journal of Agricultural Science and Technology 19: 1527-1537.

Meisami-asl, E., S. Rafiee, A. Keyhani, and A. Tabatabaeefar. 2010. Determination of suitable thin layer drying curve model for apple slices (variety-Golab). Plant Omics Journal 3: 103-108.

Murni, M., dan M. E. Hartati. 2010. Pengaruh perlakuan awal dan blansing terhadap umur simpan cabai merah kering. Berita Litbang Industri XLV: 45-51.

Nalawade, S. A., A. Sinha, dan H. U. Hebbar. 2018. Infrared based dry blanching and hybrid drying of bitter gourd slices: process efficiency evaluation. Journal of Food Process Engineering 41: 1-11. DOI: 10.1111 /jfpe. 12672

Niartika, N. 2018. Effect of Processing on the Antioxidant Content and Physical Characteristics of Chilli Pepper (Capsicum spp.). Skripsi. Semarang: Fakultas Teknologi Pertanian, Universitas Katolik Soegijapranata.
Omolola, A.O., A.I.O. Jideani, and P.F. Kapila. 2015. Drying kinetics of banana (Musa spp.) Interciencia 40: 374-380.

Phang, H.K., Chu, C.M. Kumaresan, S., M.M. Rahman, and S.M. Yasir. 2015. Preliminary study of seaweed drying under a shade and in a natural draft solar dryer. International Journal of Science and Engineering 8: 10-14. DOI: $10.12777 / \mathrm{ijse} .8 .1 .10-14$

Prasetyo, D.J., T.H. Jatmiko, and C.D. Poeloengasih. 2018. Drying characteristics of Ulva sp. and Sargassum sp. seaweeds. JPB Kelautan dan Perikanan 13: 1-12. DOI: 10.15578/jpbkp.v13i1.515

Ramdani, H, R. Wicaksono, dan M. A. Fachruddin. 2018. Penambahan natrium metabisulfit $\left(\mathrm{Na}_{2} \mathrm{~S}_{2} \mathrm{O}_{5}\right)$ terhadap vitamin $\mathrm{C}$ dan warna pada proses pengeringan cabai merah (Capsicum annuum L.) dengan tunnel dehydrator. Jurnal Agronida 4: 88-97. DOI: 10.30997/jag.v4i2.1572

Rocha, T., A. Lebert, and C. Marty-Audouin. 1993. Effect of pretreatments and drying conditions on drying rate and colour retention of basil (Ocimum basilicum). LWT-Food Science and Technology 26: 456-463. DOI: 10.1006/fstl. 1993.1090

Rozana, R., R. Hasbullah, dan T. Muhandri. 2016. Respon suhu pada laju pengeringan dan mutu manisan mangga kering (Mangifera indica L.). Jurnal Keteknikan Pertanian 4: 59-66. DOI: 10.19028/jtep.04.1.\%25p

Santoso, D., D. Muhidong, dan M. Mursalim. 2018. Model matematis pengeringan lapisan tipis biji kopi arabika (Coffeae arabica) dan biji kopi robusta (Coffeae cannephora). Jurnal Teknologi Pertanian Andalas 22: 86-95. DOI: $10.25077 /$ jtpa.22.1.86-95.2018

Silva, K.D.S., L.C. Caetano, C.C. Garcia, J.T. Romero, A.B. Santos, and M.A. Mauro. 2011. Osmotic dehydration process for low temperature blanched pumpkin. Journal of Food Engineering 105: 56-64. DOI: 10.1016/j.jfoodeng.2011.01.025

Suhendar, E., Tamrin, dan D.D. Novita. 2017. Uji kinerja alat pengering tipe rak pada pengeringan chip sukun menggunakan energi listrik. Jurnal Teknik Pertanian Lampung 6: 125-132.

Syam, H., P. Jamaluddin, M. Rais, dan N. Lestari. 2019. Potensi panas terbuang kondensor AC sebagai sumber pemanas pada cabinet dryer. In Seminar Nasional LP2M UNM. 
Tao, Y., M. Han, X. Gao, Y. Han, P.L. Show, C. Liu, X. Ye, and G. Xie. 2019. Applications of water blanching, surface contacting ultrasound-assisted air drying, and their combination for dehydration of white cabbage: drying mechanism, bioactive profile, color and rehydration property. Ultrasonics Sonochemistry 53: 192-201. DOI: 10.1016/j.ultsonch.2019.01.003

Tunde-Akintunde, T.Y. 2010. Effect of pretreatment on drying time and quality of chilli pepper. Journal of Food Processing and Preservation 34: 595-608. DOI: 10.1111/j.1745-4549.2008.00360.x

Usman, U., A. Muchtar, U. Muhammad, dan N. Lestari. (2020). Purwarupa dan kinerja pengering gabah hybrid solar heating dan photovoltaic heater dengan sistem monitoring suhu. Jurnal Teknik Elektro 12: 24-32. DOI: 10.15294/jte.v12i1.24028

Zakipour, E. and Z. Hamidi. 2011. Vacuum drying characteristics of some vegetables. Iranian Journal of Chemistry and Chemical Engineering 30: 97-105.

Copyright ( 2021 Andi Muhammad Irfan, Nunik Lestari, Arimansyah, A. Ramli Rasyid

This work is licensed under a Creative Commons Attribution-ShareAlike 4.0 International License. 